\title{
Factors Affecting the Use of Costing Systems toward Managerial Performance in Vietnamese Public Hospitals
}

\author{
NGUYEN PHONG NGUYEN \\ University of Economics HCMC - nguyenphongnguyen@ueh.edu.vn \\ NGUYEN DUNG HAI \\ University of Economics HCMC - dunghai@ ueh.edu.vn \\ TRAN ANH HOA \\ University of Economics HCMC - tranhhoa@ueh.edu.vn
}

\section{ARTICLE INFO ABSTRACT}

Article history:

Received:

May 222015

Received in revised form:

Oct. 272015

Accepted:

Mar. 252016

Keywords:

Costing systems, top management support, decentralization, technical validity, perceived environmental uncertainty, public hospitals.
This study investigates contextual and behavioral factors affecting the use of costing systems toward managerial performance among Vietnam's public hospitals. The PLS-SEM results based on survey data from 262 mid-level managers from various departments indicate that top management support, decentralization of decision making, perceived technical validity, and perceived environmental uncertainty are important drivers of the use of costing systems, which in turn enhances task performance. The findings suggest that Vietnamese public hospitals should not underestimate the contextual and behavioral factors involved in facilitating the functioning of costing systems toward better performance outcomes. This study adds to limited research on behavioral accounting in Vietnamese public hospitals. 


\section{Introduction}

Public hospitals play a pivotal role in the health care and medical systems of Vietnam. In 2014 the health care system had 1,349 hospitals with 260,058 activated beds; there were 1,179 public hospitals in total, representing $87.3 \%$ of the number of hospitals across the country (Hieu, 2015). The shifting of the Vietnamese economy from closed and centralized toward an open market in the late 1980s led to many adjustments in the regulations of Vietnamese health care and medical systems from being fully regulated and supported by the government to a more liberalized system with less regulation and government subsidy. Therefore, the public hospital sector, as a part of the health care and medical systems, experienced a restructuring program that resulted in changes in the regulatory system and placed greater emphasis on finance through the application of user fees, the development of health insurance schemes, and the granting of autonomy (Pham, 2011).

The liberalization of the health care system, nevertheless, places enormous competitive pressure on public hospitals while government funds are more and more limited, and public hospitals have to compete with competitors in the growing private health care sector. The observation is that while private hospitals are attracting more of the wealthy who can afford expensive imported drugs and sterling services, public ones are losing both funds and patients, leaving under-resourced services for the poor (Ladinsky et al., 2000). The competitive pressure has forced Vietnamese public hospitals to change their operations quickly to meet increasing requirements for improvement in operating efficiency. The need for improvement is made even more urgent by various kinds of constraints facing public hospitals, for example, very poor resources for technological development, limited capability of doctors in acknowledging and adopting new medical techniques, and lack of concern by hospital managers regarding new technologies (Pham, 2011). Operating efficiency, therefore, is vital, as managers need cost information in terms of hospital services (Flessa \& Dung, 2004).

The fact that Vietnamese public hospitals are operating in a more competitive environment means that they are more obliged to satisfy all market demands for health care services, and they must reduce input costs. This stresses the importance of costing systems, which are efficient tools for managers in hospitals in terms of planning, control, and making decisions. This is widely emphasized in both management accounting and health care literature (e.g., Hammad et al., 2013; Hammad et al., 2010; Pizzini, 2006). 
Given the rising cost of health care, it is clear that hospitals must attempt to increase their revenue and decrease their costs. These attempts can only be successful if managers have relevant accounting information (Pomberg et al., 2012). In keeping up with the rising importance of cost control in the hospital industry, managers are increasingly using cost information to monitor hospital operations (Brickley \& Van Horn, 2002). More functional information systems can then better link cost information to managerial decisions, hence producing performance measures that better reflect managerial performance.

Information provided by costing systems in Vietnamese public hospitals is also crucial from the government's perspective. Given that Vietnam has implemented various health care policies addressing key issues in health care reform, including health care system financing, different methods have been suggested for improving effectiveness and reducing costs in the health care industry. These improvements can only be achieved if costing systems in public hospitals provide appropriate information (Pomberg et al., 2012). As a result of a decline in governmental health care resources, patients have to spend more of their savings on hospital costs. The rapid growth of the private health care market has informed the Vietnamese that they can ask for value for money. Together, the policy makers must have new approaches to manage public hospitals toward better performance with enhanced value for patients. Since the policy makers also need cost information on hospital services, such as the costs of a particular treatment in a particular public hospital, and must then compare the costs against other hospitals, it becomes an urgent need among Vietnamese public hospitals (Flessa \& Dung, 2004).

Although the cost accounting functions in Vietnamese hospitals are being enhanced in response to regulatory and environmental changes, the improvement is still insignificant (Pomberg et al., 2012). Flessa and Dung (2004) claimed that not all existing hospitals in Vietnam have professional accountants, and in these hospitals training of accountants and managers has to be improved. In many public hospitals, medical documents and financial statements do not exist or are full of mistakes (Flessa \& Dung, 2004). For example, depreciations for many types of fixed assets are not recorded in the books, as public hospitals apply a cash basis rather than an accrual basis in preparing the accounting numbers (Flessa \& Dung, 2004). A possible reason is a lack of interest by public hospital managers in developing and using costing systems in planning, controlling, and making decisions. This is confirmed by Verbeeten (2011), who argued that political managers in public companies are reluctant to use cost accounting 
information because these managers are "at a larger distance" in these companies. The poor quality and improper use of costing systems results in a very narrow insight into the service costs from the perspectives of the health care administrators. Though cost data should be collected routinely, the local managers as decision makers are still not well-informed about the service costs in their hospitals (Flessa \& Dung, 2004). This is conducive to inappropriate planning and cost control activities of the management of public hospitals (Pomberg et al., 2012). Hence, the problem of improper use of costing systems facing the Vietnamese hospital sector is evidenced and needs to be examined throughout this study.

This study adds to the extant literature regarding costing system use and the consequences of that for task performance, as there have been few studies conducted to investigate the contextual and behavioral factors affecting the use of the costing systems in Vietnamese public hospitals. A priori, this study expects to see whether contingency theory, perceived organizational support, and the technology acceptance model can be used to explain the issue toward better managerial performance in public hospitals in Vietnam. The rest of this paper is structured as follows. The next section presents the theoretical model along with corresponding hypotheses, followed by the other sections on the research methods with sampling and measurement scales, data analysis and results, discussion of results, and conclusion.

\section{Theoretical model and hypotheses}

\subsection{Costing systems}

Costing systems are defined as integrated manual and computer components used to collect, analyze, and manage cost and operational data to provide information in order to assist managers in estimating the costs of products and services, managing costs, formulating strategy, enhancing product planning, and improving managerial decisions (Mahama \& Cheng, 2013). Since the 1980s there has been a rising interest in costing systems, which has been triggered by changes in the business landscape, including manufacturing technology changes, international competition, and shorter product life cycle (Al-Omiri \& Drury, 2007).

In line with this rising interest, there have been various studies examining managerial perceptions of costing systems in three phases of costing system development: design, implementation, and post-implementation. Some researchers have focused on the 
technical aspects of costing systems in the costing system design phase to investigate the benefits of using them. For example, Pizzini (2006) examined the role of costing system functionality in explaining managers' evaluation of the usefulness and relevance of cost data; Ittner et al. (2002) investigated the relationship between the extent of use of activity-based cost systems and performance outcomes such as cost reductions via improvements in quality and cycle time; Abernethy and Lillis (2001) studied the influence of cost structure, product diversity, and process complexity on the choices of costing system design. Others in the area of activity-based costing/management literature have emphasized the implementation phase of costing system development. For instance, Chenhall (2004) revealed that activity-based cost management (ABCM) implementation factors (top management support, clarity of objectives, and training) influence the performance outcome of the $\mathrm{ABCM}$ process via cognitive and affective conflicts; Anderson et al. (2002) examined the effect of competition (external environment) and $\mathrm{ABC}$ team characteristics on the performance of the $\mathrm{ABC}$ team.

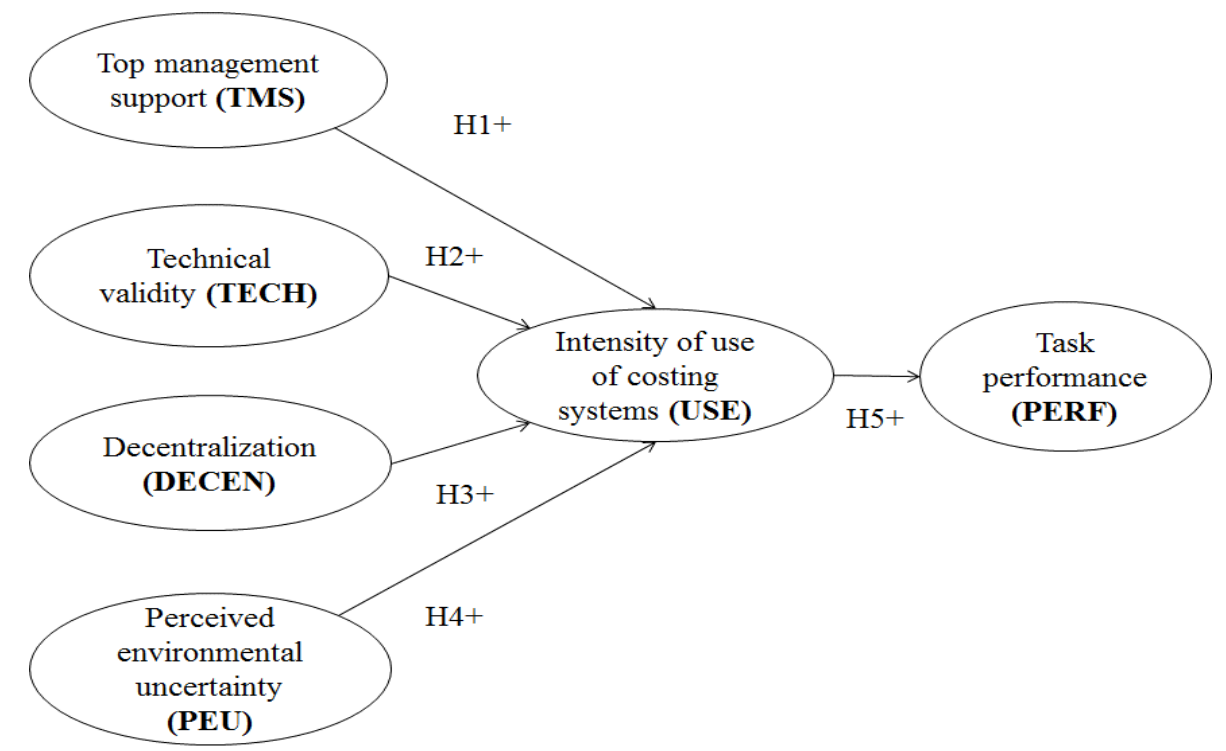

Figure 1. The theoretical model

In a study of the costing system post-implementation phase, Mahama and Cheng (2013) used data from managers from Australian listed companies and found a positive association between managerial enabling perceptions ${ }^{1}$ and costing system use. This study, however, focused only on the psychological factors and did not incorporate both organizational/contextual and behavioral factors in a model predicting the costing 
system use and the impact of this use on managerial performance. Based on the contingency theory (Chenhall, 2003), the perceived organizational support literature (Eisenberger et al., 1990), and the technology acceptance model (Davis, 1989), this study adds to the existing literature by investigating the contextual and behavioral factors associated with the post-implementation use of costing systems in the hospital setting besides addressing the outcome of the costing system use in terms of managerial task performance. The examined factors are top management support, technical validity, decentralization, and perceived environmental uncertainty. The hypothesized relationships in our theoretical model are reflected in Figure 1.

\subsection{Top management support}

Following previous studies in the information system and ERP implementation literature (e.g., Lin, 2010; Nah et al., 2003; Ragu-Nathan et al., 2004), this study defines top management support as the degree to which top managers realize the importance of costing systems and the extent to which they are involved in costing system implementation. Lin (2010) suggested that top management support is reflected by the ways in which top managers have high interest and concern in promoting the system and believe the system is worth a long-term investment that can bring competitive advantages to the organization. Top management support is also related to the allocation of adequate resources for the development of an information system (Lin, 2010; Nah et al., 2003). The most challenging issue in the implementation and operation of an information system is dealing with major changes to be made in the work procedures. These changes could encounter crises, conflicts, and resistance from various groups of stakeholders in an uncertain environment (Ragu-Nathan et al., 2004), unless there is a full commitment from top managers.

The significance of top management support and facilitation of conditions is also highlighted by Sabherwal et al. (2006) who argued that the support stimulates higher user participation and results in greater information system success, in terms of perceived usefulness, satisfaction of users, and system use. This argument is underpinned by the perceived organizational support literature (e.g., Eisenberger et al., 1990; Konradt et al., 2006; Sharma \& Yetton, 2003). Hence, in the context of hospitals, top management support is argued to have influence on the use of costing systems. Accordingly: 
H1: Top management support has a possitive effect on the intensity of costing system use.

\subsection{Technical validity}

Technical validity refers to the capability of the information system to function as required; that is, its design triggers useful and beneficial information outputs. This relates to the ability of the information system to provide accurate, accessible, reliable, timely, and understandable information (McGowan, 1998). The accounting literature has also identified at least four quality criteria reflecting the technical validity of a costing system. These criteria include the level of cost details, the ability of the system in classifying costs in terms of cost behavior, and the frequency of information reported (Pizzini, 2006).

It can be argued that costing systems with a high level of technical validity can classify costs effectively in terms of cost behavior, provide greater cost details, and supply cost information more frequently. In hospitals managers have to make various decisions regarding the services to be delivered to patients (i.e. tests, diagnoses). Furthermore, managers have to interact with physicians, therapists, doctors, nurses, etc., who supply these services, and also the entities (i.e. insurance firms and government agencies) that pay for the services. Unless costing systems can classify and aggregate costs for these services and related stakeholders with a reasonable level of accuracy, good decisions cannot be made by these managers. Pizzini (2006) studied the relationships among the functionality of costing systems, managers' beliefs about the usefulness and relevance of cost information, and the financial performance of hospitals in the US. The results showed that managers in US hospitals believe that costing systems with more detailed cost data provide more relevant information, which in turn, are used to make better decisions.

Moreover, the frequency of cost reports allows managers to expediently address areas that have problems for potential improvements (Pizzini, 2006). More frequent reports also emphasize the timeliness of cost information. For instance, with more timely cost information, managers can identify problems that arise during the reporting period, rather than wait until the end of the period. Evaluating the value of an information system in a cost-volume-profit setting, Hilton (1979) found that a higher level of timeliness of information results in a greater usefulness of the information system perceived by the end users. Plainly, according to the technology acceptance model, the perceived 
usefulness is an important driver of system use (Davis, 1989). Given the positive association between perceived system usefulness and system use that is well-recognized in the information system literature (Foong \& Anak Teruki, 2009), this study posits the following:

H2: Technical validity of costing systems has a positive effect on the intensity of costing system use.

\subsection{Decentralization}

Decentralization refers to an organizational structure emphasizing the autonomy and participation of employees in decision making (Meirovich et al., 2007). In a decentralized organization, managers have greater autonomy and responsibility for planning, control, and making decisions. These decentralized managers are likely to use information that is aggregated to reflect their responsibility, and this underlies the nature of their sub-unit activities (Chenhall \& Morris, 1986). A study by Chia (1995) found that a high level of decentralization enables a higher information-processing capability, as more sophisticated information is required by managers in decision-making processes. This means that when an organizational structure becomes more decentralized, managers need to process a greater quantity and quality of information for managerial purposes (Pavlatos \& Paggios, 2009).

In the context of hospital management, Abernethy and Lillis (2001) argued that hospitals without service innovation should have fewer information requirements because they face less diversity and changes in their clinical mix. These hospitals, therefore, may not be under information constraints associated with a centralized structure. This implies that a higher degree of decentralization in hospitals is related to higher information requirements. In addition, the relationship between decentralization and participation in budgeting has been confirmed by several studies (e.g., Merchant, 1981; Chenhall, 2003). Thus, large and decentralized hospitals tend to employ sophisticated management controls and need a high level of budget participation, which obviously demands more cost information. A few studies in other countries have supported the role of decentralization and the level of cost information use in the hospital sector. For example, an Egyptian study by Hammad et al. (2013) established a positive correlation between decentralization and the degree to which costing systems are used by managers. Another study by Abernethy and Lillis (2001) on Australian public hospitals confirmed that when the level of autonomy granted to clinical units increases, 
the measures of resource and clinical management become more material, and the needs of cost information for management are therefore on the increase. Hence, the following hypothesis is proposed:

H3: Decentralization has a positive effect on the intensity of costing system use.

\subsection{Perceived environmental uncertainty}

Perceived environmental uncertainty is referred to as the degree of uncertainty an individual perceives regarding the changes in the external operating environment (Gordon \& Narayanan, 1984), including changes in technology, customers and competitors, and economic and regulatory structures. The external operating environment is a significant contextual variable determining the foundation of contingency-based research (Chenhall, 2003). The positive relationship between external operating environmental uncertainty and the supply of and demand for information has been reflected in early literature (e.g., Galbraith, 1973). In the context of high environmental uncertainty, organizations are required to process greater information to plan and respond to an unpredictable and changing environment. For instance, managers will need more information about past and future events both inside and outside their organizations (Hammad et al., 2010).

The nexus between environmental uncertainty and information demand has been widely addressed in the health care literature. The use of well-developed costing systems is strongly encouraged to assist managers to cope with increasing competitive pressure by controlling costs in the rapidly changing health care industry. Such encouragement is in line with management accounting research, which suggests that an increase in environmental uncertainty requires managers to search for more information for planning and control (Pizzini, 2006). This means that hospitals operating in markets with fierce competition and significant threats from new entrants are under high pressure to control costs and, hence, need more extensive and comprehensive cost information (Hammad et al., 2010; Hill, 2000). One can argue that when environmental uncertainty increases, there is a higher possibility that competitors will exploit any product and service cost distortions. Therefore, more accurate, timely, and detailed cost information can be employed to plan for reactions to possible competitors' movements. In light of the above reasoning, this study formulates the following hypothesis:

H4: Perceived environmental uncertainty has a positive effect on the intensity of costing system use. 


\subsection{Task performance}

This study uses the term "task performance" to indicate individual managers' performance with respect to their work tasks. Task performance is viewed as a subset of individual performance, with a focus specifically on how well individuals perform on their work tasks (Mahama \& Cheng, 2013). Previous information system studies have suggested that use of a system is an important channel through which the system generates performance outcomes at both organizational and individual levels. In particular, without use, it is impossible to observe the outcomes of the system. Seddon (1997) also indicated that the intensity of system use is not an indicator of information system success in itself, but an important variable that leads to individual and organizational influences. Likewise, it was claimed that the success of accounting information systems is positively correlated with people acceptance and usage (Chenhall, 2004). Although previous studies have not directly addressed the relationship between the use of accounting information systems and task performance, based on these prior findings on the positive associations between system usage and individual-level impacts, this study conjectures the following:

H5: The intensity of use of costing systems has a positive effect on task performance.

\section{Research methodology}

\subsection{Sampling}

This study, designed to collect data from public hospitals in Vietnam, uses a selfadministrated questionnaire. Mid-level managers in public hospitals were chosen to be potential informants. The informant choice was based on previous findings that the work of managers at mid-level varies from relatively unstructured to structured, and these managers need access to more operational information (Mahama \& Cheng, 2013). As this study focuses on testing factors affecting the use of costing systems, a sample of mid-level managers, who are the end users of the costing systems, was regarded as the most suitable. However, given the dependent variable as the use of costing systems, managers from the accounting and finance departments were excluded from the sample, since they are the providers rather than the end-users of costing information. In particular, the potential informants in hospitals included managers from human resources, general planning, logistics, nursing, marketing, purchasing departments, and 
various specialties such as accident and emergency, medicine, surgery, ancillary, and anesthesiology.

Survey forms were sent to these potential informants in nine public hospitals (to which the authors could get access using a convenient approach) in Ho Chi Minh City, the largest economic center of Vietnam. After two weeks a second wave of survey forms was sent to all non-respondents. In total there were 262 usable surveys returned, corresponding to a response rate of $63.3 \%$. These 262 respondents have a mean of 9.1 years ( standard deviation $=5.6$ years) working at their respective hospitals, and a mean of 3.6 years (standard deviation $=1.7$ years) working in their current positions. To test for non-response bias, this study follows Mahama and Cheng (2013) to compare the means of the first 10 responses and the last 10 responses and finds that these two groups are statistically indifferent in terms of all measures ( $p$-values $>0.1$, one tailed $t$-test) ${ }^{2}$. The respondents' profiles and descriptive statistics for key variables are shown in Tables 1 and 2.

\section{Table 1}

Profiles of respondents

\begin{tabular}{|c|c|c|c|c|c|}
\hline & $\begin{array}{l}\text { Frequency } \\
(n=262)\end{array}$ & Percentage & & $\begin{array}{l}\text { Frequency } \\
(n=262)\end{array}$ & Percentage \\
\hline \multicolumn{3}{|c|}{ Number of responses according to hospitals } & \multicolumn{3}{|c|}{ Number of responses according to departments } \\
\hline $\begin{array}{l}\text { Nguyen Tri Phuong } \\
\text { Hospital }\end{array}$ & 40 & $15 \%$ & Human resources & 32 & $12 \%$ \\
\hline $\begin{array}{l}\text { Binh Dan General } \\
\text { Hospital }\end{array}$ & 29 & $11 \%$ & $\begin{array}{l}\text { General planning, } \\
\text { logistics }\end{array}$ & 29 & $11 \%$ \\
\hline $\begin{array}{l}\text { Reproductive } \\
\text { Healthcare Center }\end{array}$ & 15 & $6 \%$ & Nursing & 30 & $11 \%$ \\
\hline $\begin{array}{l}\text { Ear Nose Throat } \\
\text { Hospital }\end{array}$ & 38 & $15 \%$ & Specialties & 143 & $55 \%$ \\
\hline Children Hospital 1 & 45 & $17 \%$ & $\begin{array}{l}\text { Others (e.g. } \\
\text { marketing, } \\
\text { purchasing) }\end{array}$ & $\underline{28}$ & $\underline{11 \%}$ \\
\hline $\begin{array}{l}\text { TMMC Cancer } \\
\text { Center }\end{array}$ & 18 & $7 \%$ & Total & 262 & $100 \%$ \\
\hline
\end{tabular}




\begin{tabular}{|c|c|c|c|c|c|}
\hline & $\begin{array}{l}\text { Frequency } \\
(n=262)\end{array}$ & Percentage & & $\begin{array}{c}\text { Frequency } \\
(n=262)\end{array}$ & Percentage \\
\hline $\begin{array}{l}\text { Nhan Dan Gia Dinh } \\
\text { Hospital }\end{array}$ & 27 & $10 \%$ & Gender & & \\
\hline $\begin{array}{l}115 \text { People's } \\
\text { Hospital }\end{array}$ & 20 & $8 \%$ & Male & 147 & $56 \%$ \\
\hline $\begin{array}{l}\text { Binh Thanh } \\
\text { Hospital }\end{array}$ & $\underline{30}$ & $\underline{11 \%}$ & Female & $\underline{115}$ & $\underline{44 \%}$ \\
\hline Total & 262 & $100 \%$ & Total & 262 & $100 \%$ \\
\hline \multicolumn{3}{|c|}{ Period of experience in the hospital } & \multicolumn{3}{|c|}{ Period of experience in the current position } \\
\hline$<2$ years & 37 & $14 \%$ & $<2$ year & 75 & $29 \%$ \\
\hline $2-5$ years & 42 & $16 \%$ & $2-5$ years & 134 & $51 \%$ \\
\hline $5-10$ years & 106 & $40 \%$ & $5-10$ years & 43 & $16 \%$ \\
\hline 10-20 years & 68 & $27 \%$ & $10-20$ years & 8 & $3 \%$ \\
\hline$>20$ years & $\underline{9}$ & $\underline{3 \%}$ & $>20$ years & $\underline{2}$ & $\underline{1 \%}$ \\
\hline Total & 262 & $100 \%$ & Total & 262 & $100 \%$ \\
\hline
\end{tabular}

Table 2

Descriptive statistics of key variables

\begin{tabular}{lcccc}
\hline \multicolumn{1}{c}{ Variable } & $\begin{array}{c}\text { Theoretical } \\
\text { range }\end{array}$ & $\begin{array}{c}\text { Actual } \\
\text { range }\end{array}$ & Mean & Std. dev. \\
\hline Decentralization (DECEN) & $1.00-5.00$ & $1.00-5.00$ & 3.02 & 0.97 \\
$\begin{array}{l}\text { Technical validity (TECH) } \\
\text { Top management support (TMS) }\end{array}$ & $1.00-5.00$ & $1.20-5.00$ & 3.35 & 0.94 \\
$\begin{array}{l}\text { Perceived environmental } \\
\text { uncertainty (PEU) }\end{array}$ & $1.00-7.00$ & $1.86-7.00$ & 4.36 & 1.03 \\
$\begin{array}{l}\text { Intensity of use of cost system } \\
\text { (USE) }\end{array}$ & $1.00-7.00$ & $1.00-6.63$ & 4.41 & 1.16 \\
\begin{tabular}{l} 
Task performance (PERF) \\
\hline
\end{tabular} & $1.00-7.00$ & $1.50-7.00$ & 4.36 & 1.32 \\
\hline
\end{tabular}




\subsection{Measures of constructs}

This study employs a five-point Likert scale with four items adopted from Meirovich et al. (2007) to measure decentralization using the amount of employees' autonomy and their participation in decision making. Following McGowan (1998) and Burney et al. (2009), this study evaluates the technical validity of costing systems based on five criteria in the management information systems literature, which are accuracy, accessibility, reliability, timeliness, and understandability. Top management support is rated by four five-point Likert scale items adopted from Lin (2010). Perceived environmental uncertainty measured on seven items is adopted from Kober et al. (2003) and Gordon and Narayanan (1984). Respondents were required to verify their agreement with statements pertaining to these items, on a scale ranging from $1=$ 'strongly disagree' to $7=$ 'strongly agree'. Intensity of use of costing systems in hospitals is assessed by five items based on the study of Pomberg et al. (2012). Respondents were asked to rate the degree to which they use the costing systems to facilitate some key decisions in hospitals following the scale items anchored to 1 = 'lesser extent' and 7 = 'greater extent'. To measure task performance, the seven-point Likert scale of Kathuria and Davis (2001) with six items is adapted, based on the level of perceived satisfaction of mid-level managers on their performance when they use information provided by the costing systems. The scale ranges from $1=$ 'not satisfied at all' to $7=$ 'very satisfied'. All constructs' items are outlined in Table 3.

\section{Analyses and results}

\subsection{Measurement reliability and validity}

Table 3 reports the measurement model results with primary psychometric properties (indicator loading, average variance extracted (AVE), and composite reliability) to evaluate the adequacy of outer-measurement models. The table shows that all indicator loadings are above the threshold of 0.5 , therefore demonstrating satisfactory individual item reliabilities. All composite reliabilities reflecting the internal consistency of key constructs, ranging from 0.81 to 0.87 , are higher than the recommended 0.70 (Nunnally, 1978). Moreover, AVE values for all constructs, except perceived environmental uncertainty with quite low AVE of 0.45, ranging 
from 0.52 to 0.60 , are above the 0.50 threshold. These results suggest adequate convergent validity of the outer-measurement models.

\section{Table 3}

Measures of model constructs and scale psychometric properties

\begin{tabular}{lll}
\hline Construct & Loading
\end{tabular}

Decentralization (DECEN): $A V E=0.52$; Composite reliability $=0.81$

DECEN1 The individual decision maker has a wide latitude in the choice of means to 0.71 accomplish goals

DECEN2 Employees have substantial autonomy when performing their job

DECEN3 If I had the opportunity and resources, I would love to start a business (deleted)

DECEN4 Many important decisions are made locally rather than centrally

DECEN5 The employees participate in the decision-making process

Technical validity $($ TECH): $A V E=0.54$; Composite reliability $=0.85$

$\begin{array}{llr}\text { TECH1 } & \text { Accuracy } & 0.51 \\ \text { TECH2 } & \text { Accessibility } & 0.77 \\ \text { TECH3 } & \text { Reliability } & 0.75 \\ \text { TECH4 } & \text { Timeliness } & 0.83 \\ \text { TECH5 } & \text { Understandability } & 0.77\end{array}$

Top management support $(T M S): A V E=0.60 ;$ Composite reliability $=0.86$

TSM1 Top management is highly interested in using the costing system 0.78

TSM2 Top management believes that the cost of the costing system is a long-term $\quad 0.84$ investment

TSM3 Top management is aware of the benefits of the costing system for future $\quad 0.65$ success of the hospital

TSM4 Top management has allocated adequate financial and other resources for $\quad 0.82$ the development and operation of the costing system

Perceived environmental uncertainty $(P E U): A V E=0.45$; Composite reliability $=0.85$

PEU1 Bidding for clients among hospitals is intense 


\begin{tabular}{|c|c|c|}
\hline \multicolumn{2}{|l|}{ Construct } & \multirow{2}{*}{$\frac{\text { Loading }}{0.69}$} \\
\hline PEU2 & Competition for human resources among hospitals is intense & \\
\hline PEU3 & $\begin{array}{l}\text { Many new services (e.g., new tests, quicker turnaround) have been } \\
\text { offered/introduced }\end{array}$ & 0.66 \\
\hline PEU4 & $\begin{array}{l}\text { The external environment (economic, regulatory, and technological) facing } \\
\text { this hospital is dynamic (i.e., continually changing) }\end{array}$ & 0.59 \\
\hline PEU5 & The market activities of your competitors are unpredictable & 0.65 \\
\hline PEU6 & $\begin{array}{l}\text { The tastes and preferences of your customers (e.g., doctors, hospitals) are } \\
\text { hard to predict }\end{array}$ & 0.69 \\
\hline PEU7 & $\begin{array}{l}\text { The legal, political, and economic constraints surrounding this hospital are } \\
\text { considerable }\end{array}$ & 0.66 \\
\hline \multicolumn{3}{|c|}{ Intensity of use of costing system (USE): $A V E=0.54 ;$ Composite reliability $=0.85$} \\
\hline USE1 & Choice of medical treatments & 0.82 \\
\hline USE2 & Choice of hospital specialization & 0.71 \\
\hline USE3 & Choice of infrastructure & 0.73 \\
\hline USE4 & Hiring and firing & 0.72 \\
\hline USE5 & Choice/method of logistics & 0.69 \\
\hline \multicolumn{3}{|c|}{ Task performance $(P E R F): A V E=0.53 ;$ Composite reliability $=0.87$} \\
\hline PERF1 & Accuracy of work performed & 0.74 \\
\hline PERF2 & Quantity of work performed & 0.73 \\
\hline PERF3 & Quality of work performed & 0.75 \\
\hline PERF4 & Operating efficiency & 0.70 \\
\hline PERF5 & Productivity & 0.75 \\
\hline PERF6 & Timeliness in meeting deadlines & 0.71 \\
\hline
\end{tabular}

This study also follows the procedure recommended by Fornell and Larcker (1981) to evaluate the discriminant validity of the key constructs. As demonstrated in Table 4, the square roots of the AVEs (from 0.67 to 0.77 ) are consistently higher than all corresponding correlations, hence confirming discriminant validity. Moreover, discriminant validity among constructs is attained when the correlation between two 
constructs (the off-diagonal entries) is not greater than their respective composite reliabilities. Table 4 also shows that no individual correlations (from 0.12 to 0.65 ) are higher than their respective reliabilities (from 0.81 to 0.87 ), thus indicating satisfactory discriminant validity of all constructs.

\section{Table 4}

Discriminant validity and tests of differences between correlations.

\begin{tabular}{|c|c|c|c|c|c|c|}
\hline & 1 & 2 & 3 & 4 & 5 & 6 \\
\hline 1. DECEN & $0.72(0.81)$ & & & & & \\
\hline 2. PERF & 0.23 & $\begin{array}{c}0.73 \\
(0.87)\end{array}$ & & & & \\
\hline 3. PEU & 0.35 & 0.45 & $\begin{array}{c}0.67 \\
(0.85)\end{array}$ & & & \\
\hline 4. TECH & 0.29 & 0.32 & 0.31 & $0.73(0.85)$ & & \\
\hline 5. TMS & 0.12 & 0.23 & 0.25 & 0.16 & $\begin{array}{c}0.77 \\
(0.86)\end{array}$ & \\
\hline 6. USE & 0.47 & 0.56 & 0.65 & 0.52 & 0.40 & $0.73(0.85)$ \\
\hline
\end{tabular}

Note: Bold diagonal entries are the square root of AVE with composite reliabilities in brackets; others are correlation coefficients.

\subsection{Common-method bias}

As this study features a collection of cross-sectional data using a key informant approach, a potential problem remains with common method bias that could cause spuriousness in relationships among the variables in the model (Podsakoff et al., 2003). This study also assesses common method bias using a Harman's single-factor test. The results show that there is no single factor accounting for the majority of the variance (the first factor accounts for $25.6 \%$ of the $62.7 \%$ explained variance). In addition, this study employs the marker-variable technique recommended by Lindell and Whitney (2001). In particular, emotional empathy is chosen as a marker variable to control for common method variance $(\mathrm{rM}=0.12)$. The mean change in correlations of the key constructs $(\mathrm{rU}$ - rA) when partialling out the effect of rM is 0.06, suggesting no evidence of common method bias (see also Malhotra et al., 2006). 


\subsection{Model fit}

To evaluate the fitness of both inner-structural and outer-measurement models to the data simultaneously, the goodness-of-fit index $(\mathrm{GoF})$ is computed following Henseler and Sarstedt (2013) by taking the square root of the product of the average communality of all constructs and the average R2 value of the endogenous constructs as: GoF $=$

$\sqrt{\overline{\text { Communality }} \times \overline{R^{2}}}$. Drawing upon the categorization of R2 effect sizes by Cohen (2013) and using the 0.5 threshold for communality (Fornell and Larcker, 1981), GoF criteria for small, medium, and large effect sizes are $0.1,0.25$, and 0.36 respectively (Wetzels et al., 2009). The computed GoF for the model is 0.50 , demonstrating good fit of the proposed model to the data.

\subsection{Hypotheses testing}

This study employs partial least squares (PLS) to estimate the theoretical model. To provide evidence for testing the proposed hypotheses, the strength and significance of individual paths are evaluated with respect to the predictive relevance of these individual paths in the theoretical model. The indices used to assess the predictive relevance of individual paths are reported in Table 5, including beta coefficients, t-values, individual variance due-to-path, along with R2 for each endogenous construct. Average variance accounted for (AVA) is also used to examine the predictive relevance of the structural model. All indices are calculated on the basis of 200 bootstrapping sampling times.

The results as shown in Table 5 indicate that the predictive relevance of the theoretical model, evaluated via the average variance accounted for (AVA), is of good magnitude at 0.47 . Furthermore, two R2 values for all of the predicted variables (USE and PERF) are greater than the recommended level of 0.10 (Falk \& Miller, 1992). The first hypothesis, which argues that top management support positively affects the intensity of use of costing systems, is supported $(\beta=0.22, t=8.09)$. Similarly, the second one, which argues that technical validity positively influences the intensity of use of costing systems $(\beta=0.29 ; \mathrm{t}=10.11)$, is supported. Decentralization does significantly affect the use of costing systems $(\beta=0.21 ; \mathrm{t}=6.80)$, thus confirming the third proposed hypothesis. Perceived environmental uncertainty also has a positive significant impact on the use of costing systems $(\beta=0.43 ; \mathrm{t}=12.50)$, therefore allowing the fourth hypothesis to be accepted. The last hypothesis, which predicts a positive effect of the 
intensity of use of costing systems on task performance, is also supported $(\beta=0.57 ; \mathrm{t}=$ 21.63).

\section{Table 5}

Partial least squares results for hypothesized relationships

\begin{tabular}{lccccl}
\hline \multicolumn{1}{c}{ Hypothesized path } & $\begin{array}{c}\text { Path } \\
\text { weights } \\
(\beta)\end{array}$ & $\begin{array}{c}\text { Variance } \\
\text { due-to- } \\
\text { path }\end{array}$ & $R^{2}$ & $\begin{array}{c}\text { Critical } \\
\text { ratio } \\
(t \text {-value })\end{array}$ & Result \\
\hline Hypothesis 1: TMS ---> USE & 0.22 & 0.09 & 0.62 & $8.09\left(^{*}\right)$ & Supported \\
Hypothesis 2: TECH ---> USE & 0.29 & 0.15 & $10.11\left(^{*}\right)$ & Supported \\
Hypothesis 3: DECEN ---> USE & 0.21 & 0.10 & $6.80\left(^{*}\right)$ & Supported \\
Hypothesis 4: PEU ---> USE & 0.43 & 0.28 & $12.50(*)$ & Supported \\
Hypothesis 5: USE ---> PERF & 0.57 & 0.32 & 0.32 & $21.63(*)$ & Supported \\
\hline AVA & & & 0.47 & & \\
\hline
\end{tabular}

${ }^{*} \mathrm{p}<0.01$; variance due-to-path is the absolute value of the product of the path weight and the correlation coefficient between the predictor variable and the predicted variable.

\section{Discussion and conclusion}

Information provided by costing systems is considered important to public hospitals since it provides public hospital management with insights to manage and control costs and activities toward enhancing managerial accountability and performance. Via a tested model against survey data from 262 mid-level managers working at nine public hospitals in Vietnam, this study verifies some contextual and behavioral factors that explain the use of current costing systems in these hospitals. In particular, the extent to which the costing systems are used by managers is positively associated with perceived top management support, decentralization of decision-making, technical validity of costing systems, and perceived environmental uncertainty. Ultimately, through an increased intensity of use of costing systems, the task performance of managers in public hospitals is enhanced.

Our study has a theoretical implication for the behavioral accounting literature. It adds to limited research on behavioral factors affecting the use of cost systems within the hospital context in such a developing country as Vietnam. The findings highlight the importance of contextual and behavioral elements as sources of enhancing the use of 
cost information toward improving managerial performance. Our study also has implications from the managerial perspective. The results suggest that in addition to the technical design, costing systems developers in Vietnamese public hospitals should consider user perceptions. Attention should be paid to perceptions of top management support, and environmental uncertainty from the view of managers, which are material antecedents of costing systems usage toward task performance. Our findings also provide top managers with a deeper understanding of how to achieve task performance using organizational factors (decentralization) and enhanced quality of costing systems.

The present study, however, is subject to several limitations. First, the interpretation of the results is limited due to our use of subjective and self-reported measures. More objective measures are recommended to be adopted in future studies to complement selfreports in estimating task performance. Considering the limitation of single-source data, it can be observed that employing a multiple informant research design may provide more insights into the relationships investigated, increase confidence in the results, and further facilitate the generalizability of the findings in further research. Second, there exists a methodological limitation in terms of scale development. The scale for perceived environmental uncertainty scarcely meets the 0.50 threshold for variance extracted, suggesting that measurement error could induce bias in the interpretation of the significant effect for this variable (Iyer et al., 1997). Finally, some notable omitted variables are organizational factors, such as resistance to using the costing systems by users of accounting information, perceived complexity of costing systems, lack of relevant skills and knowledge in accounting and finance, lack of a perceived need by mid-level managers in using costing systems, and cost of implementing/using/maintaining a costing system, all of which are likely to influence use of costing systems and should be incorporated as independent variables in future research

\section{Notes}

\footnotetext{
${ }^{1}$ An organizational technology that helps managers to deal effectively with work contingencies

${ }^{2}$ In this study, the traditional " first-last" comparison to proxy for non-response bias was used because it is impossible to identify the non-respondents and their characteristics.
} 


\section{References}

Abernethy, M. A., \& Lillis, A. M. (2001). Interdependencies in organization design: A test in hospitals. Journal of Management Accounting Research, 13(1), 107-129.

Al-Omiri, M., \& Drury, C. (2007). A survey of factors influencing the choice of product costing systems in UK organizations. Management Accounting Research, 18(4), 399-424.

Anderson, S. W., Hesford, J. W., \& Young, S. M. (2002). Factors influencing the performance of activity based costing teams: A field study of $\mathrm{ABC}$ model development time in the automobile industry. Accounting, Organizations and Society, 27(3), 195-211.

Brickley, J. A., \& Van Horn, R. L. (2002). Managerial incentives in nonprofit organizations: Evidence from hospitals. Journal of Law and Economics, 45(1), 227-249.

Burney, L. L., Henle, C. A., \& Widener, S. K. (2009). A path model examining the relations among strategic performance measurement system characteristics, organizational justice, and extra-and in-role performance. Accounting, Organizations and Society, 34(3), 305-321.

Chenhall, R. H. (2003). Management control systems design within its organizational context: Findings from contingency-based research and directions for the future. Accounting, Organizations and Society, 28(2), 127-168.

Chenhall, R. H. (2004). The role of cognitive and affective conflict in early implementation of activity-based cost management. Behavioral Research in Accounting, 16(1), 19-44.

Chenhall, R. H., \& Morris, D. (1986). The impact of structure, environment, and interdependence on the perceived usefulness of management accounting systems. Accounting Review, 61(1), 16-35.

Chia, Y. M. (1995). Decentralization, management accounting system (MAS), information characteristics and their interaction effects on managerial performance: A Singapore study. Journal of Business Finance \& Accounting, 22(6), 811-830.

Cohen, J. (2013). Statistical power analysis for the behavioral sciences (Vol. 2). Hillsdale, NJ.: Lawrence Erlbaum Associates.

Davis, F. D. (1989). Perceived usefulness, perceived ease of use, and user acceptance of information technology. MIS Quarterly, 13(3), 319-340.

Eisenberger, R., Fasolo, P., \& Davis-LaMastro, V. (1990). Perceived organizational support and employee diligence, commitment, and innovation. Journal of Applied Psychology, 75(1), 51-59.

Falk, R. F., \& Miller, N. B. (1992). A primer for soft modeling. Akron, Ohio: University of Akron Press.

Flessa, S., \& Dung, N. T. (2004). Costing of services of Vietnamese hospitals: Identifying costs in one central, two provincial, and two district hospitals using a standard methodology. The International Journal of Health Planning and Management, 19(1), 63-77.

Foong, S.-Y., \& Anak Teruki, N. (2009). Cost-system functionality and the performance of the Malaysian palm oil industry. Asian Review of Accounting, 17(3), 212-225.

Fornell, C., \& Larcker, D. F. (1981). Evaluating structural equation models with unobservable variables and measurement error. Journal of Marketing Research, 18(1), 39-50. 
Galbraith, J. R. (1973). Designing complex organizations. Boston, MA: Addison-Wesley Longman Publishing Co., Inc.

Gordon, L. A., \& Narayanan, V. K. (1984). Management accounting systems, perceived environmental uncertainty and organization structure: An empirical investigation. Accounting, Organizations and Society, 9(1), 33-47.

Hammad, S. A., Jusoh, R., \& Ghozali, I. (2013). Decentralization, perceived environmental uncertainty, managerial performance and management accounting system information in Egyptian hospitals. International Journal of Accounting and Information Management, 21(4), 314-330.

Hammad, S. A., Jusoh, R., \& Yen Nee Oon, E. (2010). Management accounting system for hospitals: A research framework. Industrial Management \& Data Systems, 110(5), 762-784.

Henseler, J., \& Sarstedt, M. (2013). Goodness-of-fit indices for partial least squares path modeling. Computational Statistics, 28(2), 565-580.

Hill, N. T. (2000). Adoption of costing systems in US hospitals: An event history analysis 1980-1990. Journal of Accounting and Public Policy, 19(1), 41-71.

Hilton, R. W. (1979). The determinants of cost information value: An illustrative analysis. Journal of Accounting Research, 17(2), 411-435.

Ittner, C. D., Lanen, W. N., \& Larcker, D. F. (2002). The association between activity-based costing and manufacturing performance. Journal of Accounting Research, 40(3), 711-726.

Iyer, V. M., Bamber, E. M., \& Barefield, R. M. (1997). Identification of accounting firm alumni with their former firm: Antecedents and outcomes. Accounting, Organizations and Society, 22(3), 315336.

Kathuria, R., \& Davis, E. B. (2001). Quality and work force management practices: The managerial performance implication. Production and Operations Management, 10(4), 460-477.

Kober, R., Juliana, Ng., \& Paul, B. (2003). Change in strategy and MCS: A match over time? Advances in Accounting, 20, 199-232.

Konradt, U., Christophersen, T., \& Schaeffer-Kuelz, U. (2006). Predicting user satisfaction, strain and system usage of employee self-services. International Journal of Human-Computer Studies, 64(11), 1141-1153.

Ladinsky, J. L., Nguyen, H. T., \& Volk, N. D. (2000). Changes in the health care system of Vietnam in response to the emerging market economy. Journal of Public Health Policy, 21(1), 82-98.

Lin, H.-F. (2010). An investigation into the effects of IS quality and top management support on ERP system usage. Total Quality Management, 21(3), 335-349.

Lindell, M. K., \& Whitney, D. J. (2001). Accounting for common method variance in cross-sectional research designs. Journal of Applied Psychology, 86(1), 114-121.

Mahama, H., \& Cheng, M. M. (2013). The effect of managers' enabling perceptions on costing system use, psychological empowerment, and task performance. Behavioral Research in Accounting, 25(1), 89-114. 
Malhotra, N. K., Kim, S. S., \& Patil, A. (2006). Common method variance in IS research: A comparison of alternative approaches and a reanalysis of past research. Management Science, 52(12), 1865-1883.

McGowan, A. S. (1998). Perceived benefits of ABCM implementation. Accounting Horizons, 12(1), 31-50.

Meirovich, G., Brender-Ilan, Y., \& Meirovich, A. (2007). Quality of hospital service: The impact of formalization and decentralization. International Journal of Health Care Quality Assurance, 20(3), 240-252.

Merchant, K. A. (1981). The design of the corporate budgeting system: Influences on managerial behavior and performance. Accounting Review, 56(4), 813-829.

Nah, F. F.-H., Zuckweiler, K. M., \& Lee-Shang Lau, J. (2003). ERP implementation: Chief information officers' perceptions of critical success factors. International Journal of HumanComputer Interaction, 16(1), 5-22.

Nunnally, J. C. (1978). Psychometric theory. NY: McGraw-Hill.

Pavlatos, O., \& Paggios, I. (2009). A survey of factors influencing the cost system design in hotels. International Journal of Hospitality Management, 28(2), 263-271.

Pham, T. L. (2011). Efficiency and productivity of hospitals in Vietnam. Journal of Health Organization and Management, 25(2), 195-213.

Pizzini, M. J. (2006). The relation between cost-system design, managers' evaluations of the relevance and usefulness of cost data, and financial performance: An empirical study of US hospitals. Accounting, Organizations and Society, 31(2), 179-210.

Podsakoff, P. M., MacKenzie, S. B., Lee, J.-Y., \& Podsakoff, N. P. (2003). Common method biases in behavioral research: A critical review of the literature and recommended remedies. Journal of Applied Psychology, 88(5), 879-903.

Pomberg, M., Pourjalali, H., Daniel, S., \& Kimbro, M. B. (2012). Management accounting information systems: A case of a developing country: Vietnam. Asia-Pacific Journal of Accounting \& Economics, 19(1), 100-114.

Ragu-Nathan, B. S., Apigian, C. H., Ragu-Nathan, T., \& Tu, Q. (2004). A path analytic study of the effect of top management support for information systems performance. Omega, 32(6), 459-471.

Sabherwal, R., Jeyaraj, A., \& Chowa, C. (2006). Information system success: Individual and organizational determinants. Management Science, 52(12), 1849-1864.

Seddon, P. B. (1997). A respecification and extension of the Delone and Mclean model of IS success. Information Systems Research, 8(3), 240-253.

Sharma, R., \& Yetton, P. (2003). The contingent effects of management support and task interdependence on successful information systems implementation. MIS Quarterly, 27(4), 533556.

Trung Hieu. (2015). Year 2014 in review: A focus on clinical process improvement and cutting hospital overcrowding (in Vietnamese). Retrieved from http://www.nhandan.com.vn/mobile/hangthang/tieu-diem/item/25254002 
Verbeeten, F. H. (2011). Public sector cost management practices in the Netherlands. International Journal of Public Sector Management, 24(6), 492-506.

Wetzels, M., Odekerken-Schröder, G., \& Van Oppen, C. (2009). Using PLS path modeling for assessing hierarchical construct models: Guidelines and empirical illustration. MIS Quarterly, 33(1), 177-195. 